\title{
高温下における岩石ブロックの熱応カによる 破壊挙動
}

\author{
木下直人 $1 \cdot$ 若林成樹 $2 \cdot$ 石田 毅 $^{3} \cdot$ 中川浩二 4 \\ 1 正会員 工博 (侏地層科学研究所（テ242-0024 神奈川県大和市福田2604-15-8） \\ 2 正会員 工修 清水建設(侏) 技術研究所（†135-8530 東京都江東区越中島3-4-17） \\ 3 正会員 工博 山口大学助教授 地域共同研究開発センター \\ （兼 大学院理工学研究科社会建設工学専攻 $7755-8611$ 山口県宇部市常盎台2557） \\ ${ }^{4}$ 正会員 工博 山口大学教授 工学部社会建設工学科
}

\begin{abstract}
高温下において，無拘束状態の稲田花崗岩と無拘束および拘束状態の三城目安山岩ブロックの熱応力による 破壊実験を実施した，その結果, 熱応力による破壊挙動は, 岩石の種類や拘束条件によって大きく異なるこ と，および導電ペイントを叙布する方法と A E 位置標定の二つの方法を組み合わせることによって，熱応力に よるき裂の発生・進展の状況を把握できることが確認された，同時に，高温下室内岩石試験によって得られた 物性値を用いた熱応力解析を行い, 熱破壊実験結果との対比・検討を行った，その結果, 岩石の熱破壊挙動を 予測するために熟応力解析を行う場合には, 物性値の温度依存性, 特に熱膨張特性の温度依存性を考慮するこ とが重要であり, そうすることによって，熱応力による破壊の開始位置と時間を予測できることがわかった。
\end{abstract}

Key Words : rock, high temperature, laboratory heating experiment, acoustic emission, thermal stress analysis

\section{1.はじめに}

低温下あるいは高温下において岩盤内の地下空間を利 用する場合には，掘削時における岩盤の安定性を確保す るとともに，その利用時に作用する熱応力に対する安定 性を確保することが重要である.

高温下における岩石・岩盤の熱応力に対する安定性を 検討するためには, 高温下における各種岩石・岩盤の力 学特性や熱特性とともに, 熱応力による破壊挙動につい ても明らかにする必要がある. そこで, 筆者らは, 岩石 を加熱した際の熱破壊挙動の特徵を把握すること, 熱破 壊挙動の計測手法を確立することおよび熱破壊挙動の予 測手法を確立することを目的として，その第一歩とし て, 稲田花崗岩ブロックの中央にヒーターを設置し, 熱 応力により実際に岩石を破壊させ，そのときの挙動を計 測する実験を実施した．そして，供試体の周辺を拘束し ていない条件下では, 稲田花崗岩は, 熱応力解析から予 測されるように, 供試体側面の中央部とヒーター孔孔壁 とを結ぶ最小抵抗線の方向に, 供試体側面から, 引張応 力によりき裂か溌生・進展すること, AEと弾性波速度 の測定が, 岩石の破壊を監視する有用な手法であること
等を明らかにした1)。

前回筆者らが実験を行って以降, 同様な, 熱応力によ る岩石ブロックの破壊実験が, Young ${ }^{2)}$ おびJansenら ${ }^{3)}$ によって実施されている。これらは，いずれも熱応力に よる岩石ブロックの破壊挙動の計測技術に着目してお り, 無拘束状態の花崗岩供試体を用いて, 超音波卜モグ ラフィーおよびA E 計測により，熱破壊挙動を把握する 実験を行っている. そして, これらの計測技術が, 熱応 力により発生したき裂面の存在を調べるのに有効である ことを述べている.

しかし，これらの実験結果を含めても，筆者らの当初 の目的に対しては，明らかになったことはいまだごく一 部にすぎない. 特に; 熱破壊挙動の予測に関しては, 上 に述べたいずれの実験においてもほとんと検討されてい ない. そこで, 前回の実験に続いて, 以下に示すような 内容・特徵を有する実験と検討を今回新たに実施した.

1)前回は無拘束状態の稲田花崗岩のみを実験の対象とし たが, 今回は, 次ページに述べる理由で, 稲田花崗岩と 三城目安山岩の 2 種類の岩石について実験を行った. ま た，三城目安山岩に関しては，熱破壊挙動に対する拘束 圧の影響を調べるため, 無拘束状態での実験だけでな 
く，供試体の四つの側面に拘束圧を作用させた場合につ いても実験を行った。

2)前回は，熱破壊挙動を計測するため，温度，AE発生 頻度, 弾性波速度の変化の3つを測定したが, き裂の発 生・進展については十分把握できなかった. そこで, 今 回は，加熱に伴うき裂の発生・進展状況を把握すること を主目的として, 温度, AE位置標定および導電ペイン トによるき裂の進展状況測定の 3 つの方法を用いて計測 を行った。

3)岩石を加熱した際の熱破壊挙動を予測するための解析 において，入力物性值の温度依存性を考慮することの重 要性を明らかにすることを主目的にして，無拘束状態の 稲田花崗岩と無拘束および拘束状態での三城目安山岩岩 石ブロックについて，高温下における室内岩石試験に よって得られた物性値を用いた熱伝導・熱応力解析を行 い, 実験結果との対比・検討を行った.

この新たな実験および解析の結果いくつかの新しい知 見が得られたので報告する。

\section{2. 岩石ブロックの熱応力による破壊実験の概要}

\section{（1)供試体と熱破壊の方法}

実験に用いた供試体は，茨城県産の稲田花崗岩と，福 島県産の三城目安山岩である.これら 2 種類の岩石を選 んだのは，既に高温下において室内岩石試験を実施して おり4),5)，その值を用いて熱伝導・熱応力解析を実施し，

実験結果との対比・検討を行うことが可能だからであ る. 稲田花崗岩の間隙率は約 $1 \%$, 石英, 斜長石, 微 斜長石，黒雲母を主成分鉱物としている．三城目安山岩 の間隙率は約 $19 \%$ で, 斜長石, 単斜輝石の他にクリスト バライトが含まれていることか確認されている4).

供試体の形状および熱破壊の方法は, 前回の実験1) と 同じなので，詳細に述べることは避け，要点のみを記 す。供試体の形状は， 1 辺 $300 \mathrm{~mm}$ の立方体の中心にヒー ターを挿入するための直径 $28 \mathrm{~mm}$ の円孔を上下方向に 穿ったものである. ヒーターは直径 $22 \mathrm{~mm}$, 長さ $300 \mathrm{~mm}$ であり，ヒーターと孔壁との隙間に豊浦標準砂を充填し た．供試体の側面は，温度ができるだけ変化しないよう に，ビニール製ホースを密に巻き付け，実験中ホース内 に水道水を流して冷却した．また，供試体の上下方向に 温度差が生じないようにすることにより，2次元として 扱うことができるようにするため，供試体の上下面は断 熱材で覆った。

整形後 1 週間以上室内に保存して自然乾燥させた供試 体を用いて，ヒーター表面の昇温速度 $200^{\circ} \mathrm{C} / \mathrm{h}$ で約 2 時間 30 分かけて $500^{\circ} \mathrm{C}$ まで加熱した後, 30分間一定温度を保 持した際の供試体の挙動を調べた.

供試体の熱破壊挙動に対する拘束圧の影響を調べるた

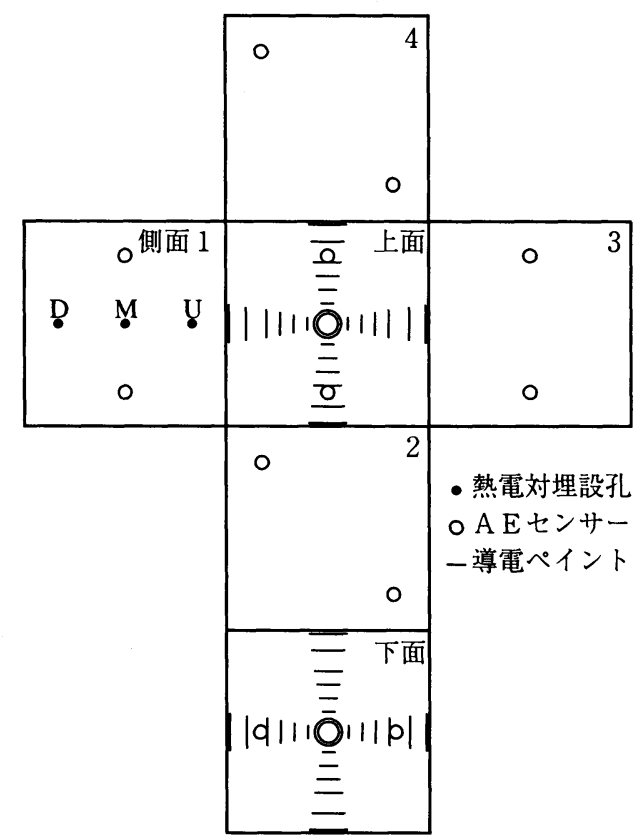

図ー1 熱電対, AEセンサーおよび導電ペイント 測定位置

め, 安山岩については, 無拘束状態での実験だけでな く, 供試体の四つの側面に拘束圧を14.7MPa作用させた 場合についても実験を行った. 拘束圧の載荷は，載荷板 を介して，油圧ジャッキを用いて行った。この場合も， 供試体の側面はできるだけ温度か湾化しないようにする ため, 載荷板内に設けた中空部分に水道水を流して供試 体の側面を冷却した．このような方法を用いることによ り, 拘束状態における実験期間中の供試体側面の温度上 昇は約 $10^{\circ} \mathrm{C}$, 無拘束状態における実験では $30 \sim 40^{\circ} \mathrm{C}$ 程度 に抑えられたことが，供試体側面の温度測定結果からわ かった.

\section{(2)加熱時の供試体挙動の測定方法}

加熱時の供試体の挙動を把握するための計測として は，温度，AE，および導電ペイントによるき裂進展状 況測定の $3 つ の$ 方法を用いた。 それらの測定位置を図一 1 に示す.

加熱時の供試体の温度変化の測定方法は前回の実験時1) と全く同じであり，供試体側面 1 の中央Mと，その上下 $100 \mathrm{~mm}$ の位置U, Dから, 直径 $8 \mathrm{~mm}$ の細孔を中心に向 けて平行に穿孔し，各孔に10本ずつ熱電対を埋設して温 度を測定した。

供試体の熱破壊挙動の測定には，AEおよび導電ペイ ントによるき裂進展状況測定の二つの方法を用いた。

$\mathrm{AE}$ E，発生頻度の計数とともに，3 次元の位置標定 が行えるよう多チャンネルで波形の観測を行った． AE 


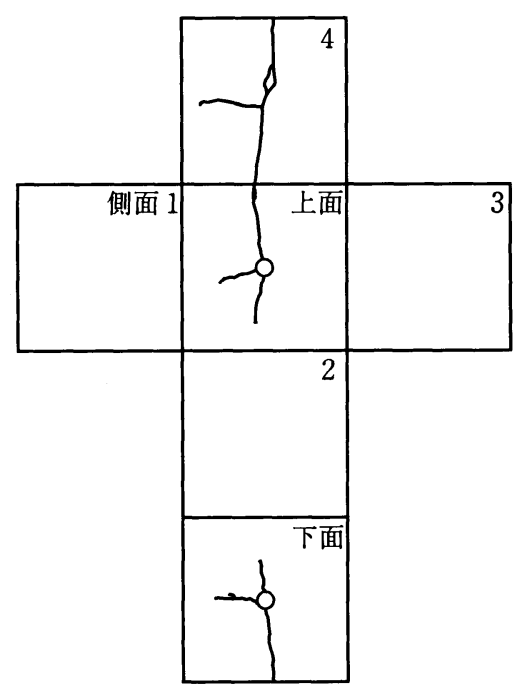

図一2 実験後の稲田花崗岩供試体表面のき裂展開図

センサーは, 共振周波数 $150 \mathrm{kHz}$ で, 直径 $17.4 \mathrm{~mm}$, 厚さ $16.3 \mathrm{~mm}$ の円柱型のものを用いたＡ A センサーの個数 は，図一 1 に示すように，供試体の各面に各 2 個合計 12 個とし，超耐熱性RTVゴムを用いて供試体表面に接着し た. A E 波形の収録には, 前回の実験と同じものを用 い, センサーで受振したAE信号を80dB増幅し，これを サンプリングタイム $0.2 \mu \mathrm{s}$ でA/D変換してフロッピー。 ディスクに収録した．AEの発生位置は，この収録波形 上で各センサーへのP波初動の到達時刻を読みとり, こ れに非線形最小 2 乗法を適用して求めた. 位置標定の精 度は10〜20 $\mathrm{mm}$ 程度である。

前回の実験結果を踏まえた予備的な検討の結果，引張 応力によりき裂が発生する場合は, 供試体側面とヒー ター孔を結ぶ最小抵抗線上を, 供試体側面の側からヒー ター孔の方向へ進展すると予想された，そこで，そのよ うなき裂の進展状況を把握できるように，上面，下面の それぞれに，図一 1 に示す位置に導電ペイントを塗布し た。また，ヒーター孔壁面から圧縮応力によりき裂が発 生する可能性もあるので, それに対応するため, ヒー ター孔周辺にも, 円形に導電ペイントを塗布した。導電 ペイント線の幅は約 $1.5 \mathrm{~mm}$ とし; き裂のわずかな開口で も導電ペイントが切断されるように，できるだけ薄く塗 布した. 過去の経験から，このような方法によって，肉 眼で明瞭に開口していると判断される幅のき裂の発生, 進展状況を確実に把握することができると考えられる. 実験中は，これらの導電ペイント線に電流を流してお き，断線した時刻を測定することによって，き裂の進展 状况を把握できるようにした。

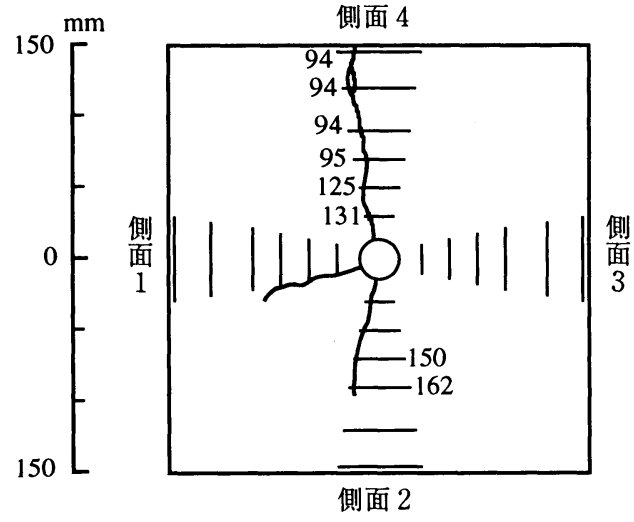

図ー3 導電ペイントの切断による稲田花崗岩供試 体上面のき裂の進展状況

(数字は加熱開始からの時間：分）

\section{3. 熱破壊実験結果}

\section{(1)稲田花崗岩（無拘束）}

実験終了後に, 目視により観察された稲田花崗岩供試 体のき裂展開図を図一2に，また，上面において，導電 ペイントが切断された時間（加熱開始からき裂がその位 置に達するまでの時間）を図一3に示す，き裂は加熱開 始94分後に，外側から発生している。このき裂は，前回 の実験において明らかにしたように1)，引張応力により発 生したと考えられる。き裂が発生したときの孔壁面の温 度 ( $\mathrm{U}, \mathrm{M}, \mathrm{D}$ の 3 点の平均値) は, 今回の実験では約

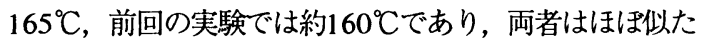
值を示している. 導電ペイントの切断状況から, 側面 4 から発生したき裂は，その後ごく短時間（1分以内）の間 に，側面から約 $80 \mathrm{~mm}$ (ヒーター孔中心から約 $70 \mathrm{~mm}$ ) のところまで進展したと考えられる. その後のき裂の進 展は比較的ゆっくりしていたと考えられ，ヒーター孔中 心から50mmおよび $30 \mathrm{~mm}$ の導電ペイントが切断された のは，それぞれ，き裂が発生してから31分後（加熱開始 125分後）および37分後 (加熱開始131分後) であり，30 ～40分かかってヒーター孔壁面に達したと考えられる.

ヒーター孔から側面 2 の方向の，3番目および 4 番目 の導電ペイントの切断状況から, 実験開始約150分後の, ヒーター温度を一定に保ち始めた頃から，新たなき裂が ヒーター孔から側面 2 の方向に向かって進展したことが わかる．このき裂は，実験終了後の目視観察により， ヒーター孔から約 $110 \mathrm{~mm}$ の位置まで達していることが確 認された，それ以外に，導電ペイントの塗布位置からず れているために，き裂の発生した時期は不明であるが, ヒーター孔から側面 1 の方向に伸びているき裂および側 面 4 のほほ中央部から水平方向に伸びているき裂が観察 


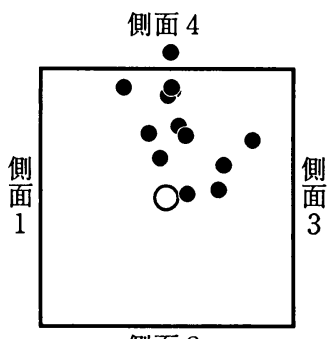

側面 2

a)き裂発生前

側面 4

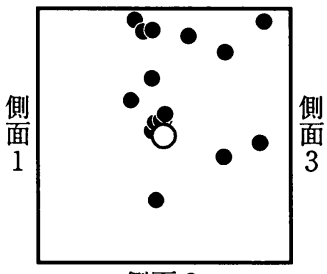

側面 2

c)き裂発生 $40 \sim 56$ 分

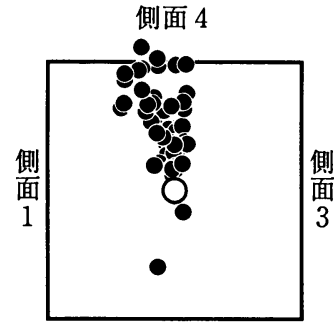

側面 2

b) き裂発生0～40分

側面 4

側面 2

b) き裂発生56分～実験終了

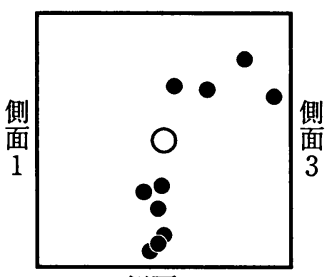

\section{図-4 稲田花崗岩供試体のAE発生位置の経時变化}

\section{されている.}

稲田花崗岩供試体について, A E 発生位置の経時変化 を求めた結果を図一 4 に示す．き裂が発生する前および き裂か溌生してから40分後までの間に発生したAEの位 置は，いずれも，主としてヒーター孔から側面 4 の方向 に向かう限られた領域内に分布しており，図一2，3に 示す最初にき裂か溌生，進展した位置に対応している。

一方，40～56分および56分～実験終了までの間に発生し たAEは，必ずしもそれに限定されない位置に分布して いる，なお，前に述べたように，実験終了後の観察によ り，ヒーター孔から側面 1 の方向に伸びているき裂およ び側面 4 のほぼ中央部から水平方向に伸びているき裂の 存在か確認されているにもかかわらず，それに対応する 位置では，いずれの時期においても A E は発生していな い.これは，これらのき裂が，AE計測終了後の供試体 冷却時に発生したためであると推測される.

側面からき裂か溌生し始めてから，き裂か孔壁面に到 達するまでの約40分間について, A E 発生位置の移動 と, 導電ペイントの切断が推定されるき裂の進展状況 とを比較してみた。き裂の周辺で発生したA Eだけに限 定して，この40分間における AEの発生位置の経時変化 を求めた結果を図一 5 に示す，同図には，導電ペイント の切断からみたき裂の先端位置の経時変化をつ印で示し てある．き裂発生直後の A E は，側面から約 $80 \mathrm{~mm}$ （ヒーター孔中心から約70mm）までの範囲で発生して おり，それより内側では全然発生していない. その後 $\mathrm{A}$ Eの発生位置は，時間の経過とともに徐々に内側の方向

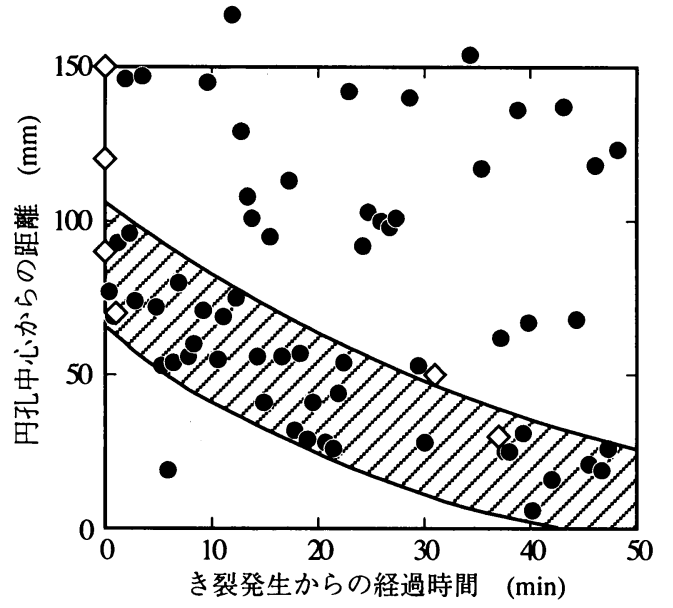

図一 5 稲田花崗岩供試体のき裂発生後のAE発生位置の 経時変化

に広がっている，AEは，き裂の先端またはそのやや前 方に相当すると思われる位置（図の斜線部分）において 発生頻度が高くなっている。 このように, AEの発生位 置の経時変化と導電ペイントの切断状況とを対比させる ことにより，AEの発生に少し遅れてき裂が徐々に進展 していく状況をよく推定することができる.

$\mathrm{AE}$ は，図一5からわかるように，き裂の先端付近た けでなく，その後方の既にき裂か形成されている位置に おいても発生している。これは，熱応力によるき裂の発 生，進展がみられる状態では，その後方の既存のき裂の 部分でもすべりが生じ，それに伴って A Eが発生してい ると考えられる.

\section{(2)三城目安山岩（無拘束および拘束）}

無拘束状態および拘束状態の三城目安山岩供試体につ いての目視によるき裂の展開図を図一6に示す。また, 無拘束供試体の上面において，導電ペイントが切断され た時間を図一7に示す．無拘束状態では，108分後に，側 面 3 から引張応力によると考えられるき裂が発生し，ほ ほ瞬時に孔壁面まで達している。なお，この時期に供試 体は明瞭な破壊音を発したことか確認されている。この

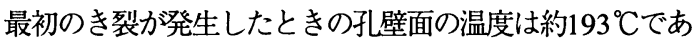
り，稲田花崗岩の場合よりも約 $28^{\circ} \mathrm{C}$ 高くなっている。 そ れ以外に，副次的に生じたと考えられる，注意深く観察 しないと発見できないような，開口していないき裂が3 本観察されている．これらのき裂の場合，いずれも実験 中には, 導電ペイントの切断は全く観測されなかった. その理由としては, ヒーター孔から側面 1 および側面 2 に向かうき裂は導電ペイントの塗布位置からずれている ため，またヒーター孔から側面 4 に向かうき裂はおそら く実験終了後の供試体の冷却時に発生したためと考えら 


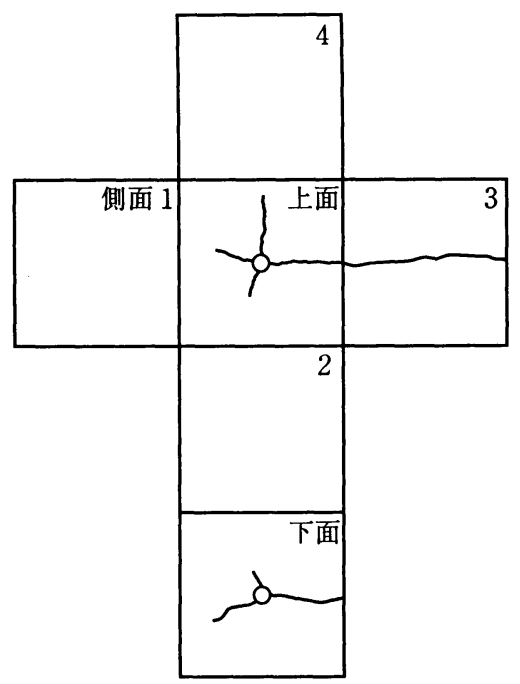

a) 無拘束状態

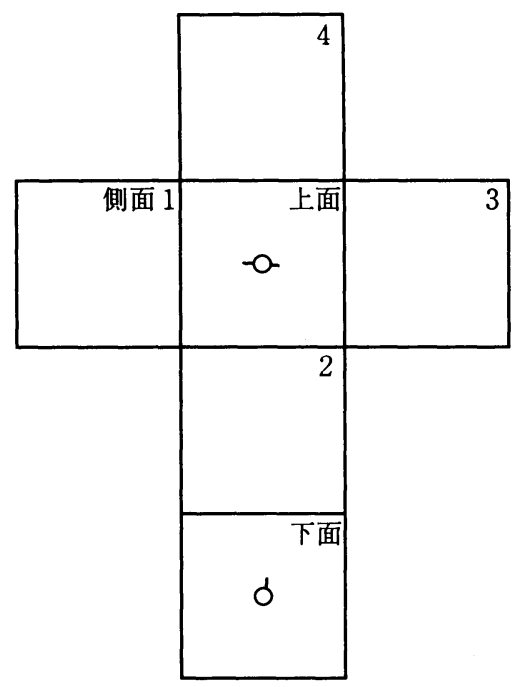

b) 拘束状態

図一 6 実験後の三城目安山岩供試体表面のき裂展開図

れる.

拘束圧下（14.7MPa）では, 無拘束状態の場合とは異 なり，内側（孔壁面）からき裂が発生している。ヒー 夕ー孔付近は, 供試体内でもっとも温度が高く, 通常加 熱に伴う膨張量が最も大きくなっており, それが周辺か ら拘束されているので, 圧縮応力が作用している. した がって，この場合には，外側からき裂が発生する場合と は異なり, 圧縮応力によりき裂が発生したと考えられ る. そのためき裂が開口するとは限らず, 導電ペイント は明暸には切断されなかったので，き裂の発生した時刻 は不明である。そして, 実験終了時までに, き裂は約 20mm進展しただけである.

無拘束状態におけるA Eの発生位置の経時変化を図一 8 に示す. 稲田花崗岩とは異なり, 加熱開始100分後まで は, AEの発生はヒーター孔近傍に分布しており, 図一 7に示すき裂が発生した位置においてAEの発生がみら れたのは，き裂の発生約 3 分前からである.き裂の発生 時からその42分後までの間は, ヒーター孔から側面 $3 に$ 向かう線上に震源が分布しており, その位置は発生した き裂の位置と対応している.き裂発生時から40分間にお けるAEの発生位置の経時変化を図一 9 に示す。き裂発 生直後から, AEは, 側面からヒーター孔壁面までの広 い範囲で発生しており，き裂がごく短時間の間にヒー ター孔壁面まで達していることがわかる.

図一8より，き裂発生42分後から実験終了までの間に 発生したAEは, ヒーター孔から側面 1 に向かう線上に 分布している. その方向は，ヒーター孔から側面 1 に向 かう方向に発生したき裂のそれとほほ一致している.

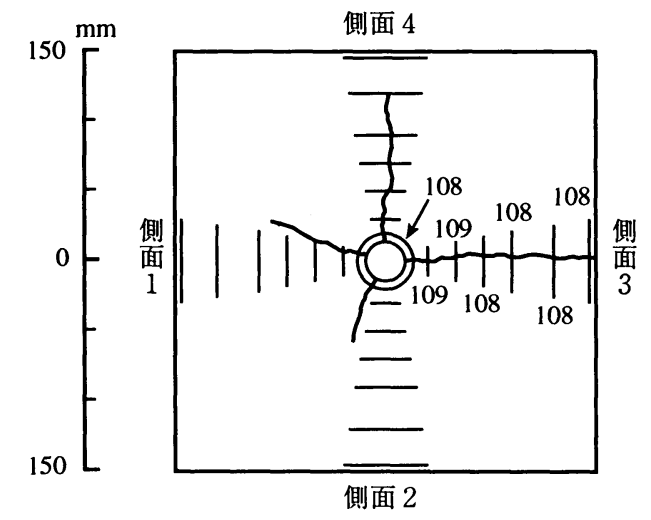

図ー7 導電ペイントの切断による三城目安山岩（無拘 束) 供試体上面のき裂の進展状況 (数字は加熱開始加らの時間：分）

拘束圧下におけるA Eの発生位置は，図一10に示すよ うに，実験期間全体を通じてヒーター孔近傍のみに集中 している。 これは，発生したき裂がごくわずかしか進展 せず, ヒーター孔近傍に限定されていることと対応して いる，ただし，AEの発生位置の経時変化から，き裂の 発生時間を推定することは困難である.

以上の結果からも明らかなように, 基本的には, 導電 ペイントを塗布する方法と A E 位置標定を行う方法とを 組み合わせることによって，熱応力によるき裂の発生， 進展の状況を把握することができた. 特に, 引張応力に よるき裂が側面からヒーター孔に向けて発生, 進展する 場合には非常に有効であった，また，圧縮応力によると 
側面 4

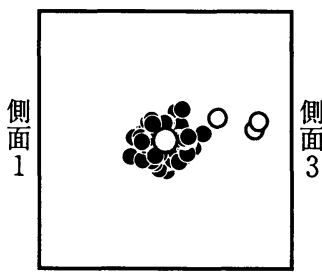

側面 2

a) き裂発生前

(○はき裂発生前3分間 に発生したAE)

側面 4

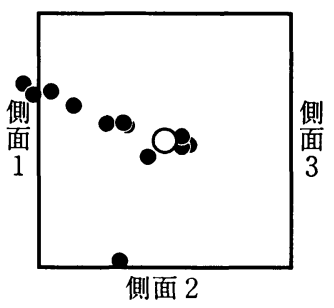

c) き裂発生 $42 \sim 56$ 分

\section{図-8 三城目安山岩（無拘束）供試体のAE発生位置の} 経時変化

思われるき裂がヒーター孔近傍に発生する場合も，それ がごくわずかしか進展しなかったことを推定することが できた。ただし，圧縮応力によりき裂か溌生する場合に は，き裂が開口するとは限らないため，き裂が発生して も, 導電ペイントが切断されない場合があること, AE の発生位置の経時変化からき裂の発生時間を推定するこ とも困難であること等により, 今回の方法ではまだ不充 分な面があることか明らかになった。

\section{4. 熱伝導・熱応力解析および実験結果の検討}

\section{(1)解析モデルと入力物性值}

岩石を加熱した際の熱破壊挙動の予測手法を確立する ことを最終目的として，本実験結果を対象にして，三角 形1 次要素を用いた 2 次元F EMにより, 非定常熱伝導 解析および弾性熱応力解析を実施した. 解析は1/4モデル で行い, 総要素数は291としているが, ヒーター孔付近は 充分に要素分割を細かくし, 解析精度の向上を図ってい る. また, 実験結果との対比を行う場合, 供試体側面に おける熱応力の計算值が重要であることから, 供試体側 面付近に関しても, 要素分割が不適切なため解析精度が 低下することがないよう配虑している.

解析には, 室内岩石試験によって得られた物性值を用 いたが, 物性値の温度依存性を考慮することの重要性を 明らかにするために, 各供試体毎に, 以下の 4 ケースに

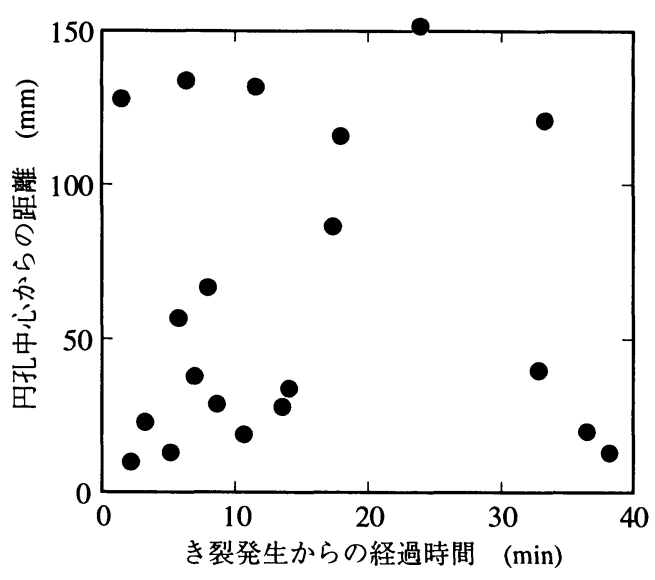

図一 9 三城目安山岩（無拘束）供試体のき裂発生後の $\mathrm{AE}$ 発生位置の経時変化

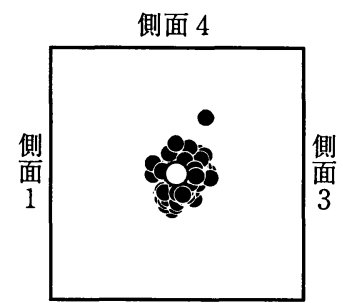

側面 2

a) 実験開始 $~ 90$ 分

側面 4

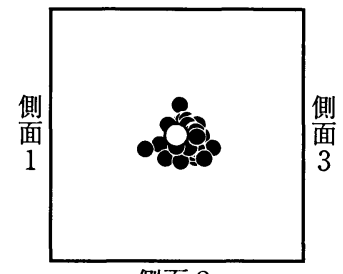

側面 2

c) 120分～実験終了

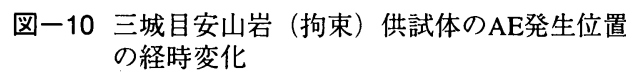

ついて解析を実施した。

ケース 1：全ての物性値について温度依存性がないと考 え，室温 $\left(20^{\circ} \mathrm{C}\right)$ におげる值を用いた場合.

ケース 2 ：熱伝導率および比熱の温度依存性だけを考慮 した場合. それ以外の物性値は温度に依存し ないものとし, 室温における值を用いた。

ケース 3 : 熱伝導率, 比熱, 静弾性係数およびポアソ ン比の温度依存性を考慮した場合.

ケース 4 ：ケース 3 に加えて更に線膨張係数の温度依 存性を考慮した場合.

熱伝導解析における境界条件は，以下のようにして定 


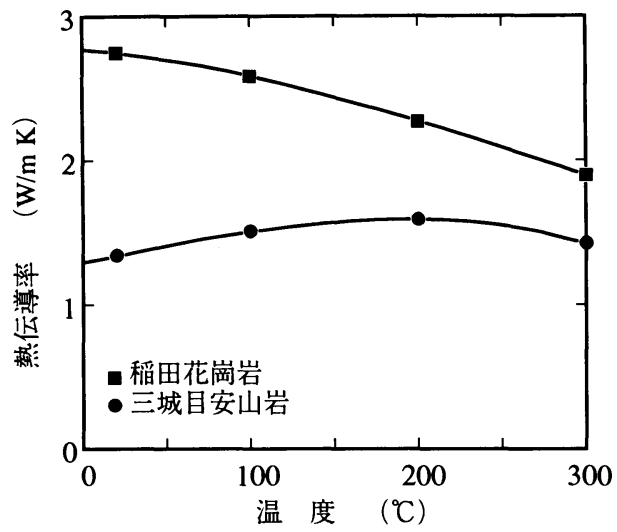

図-11 熱伝導率と温度の関係

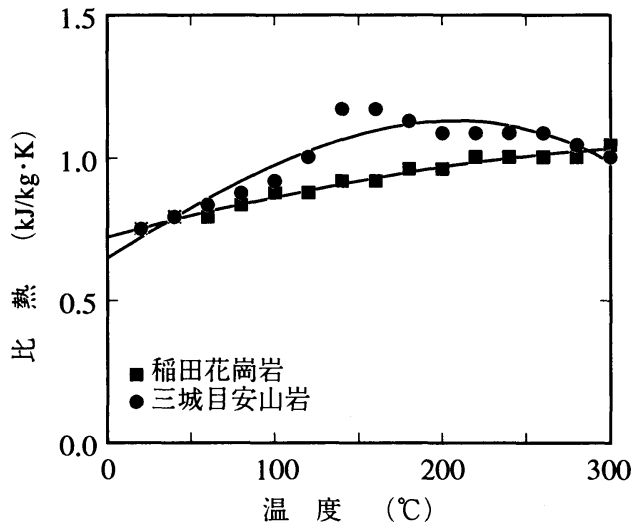

図-12 比熱と温度の関係

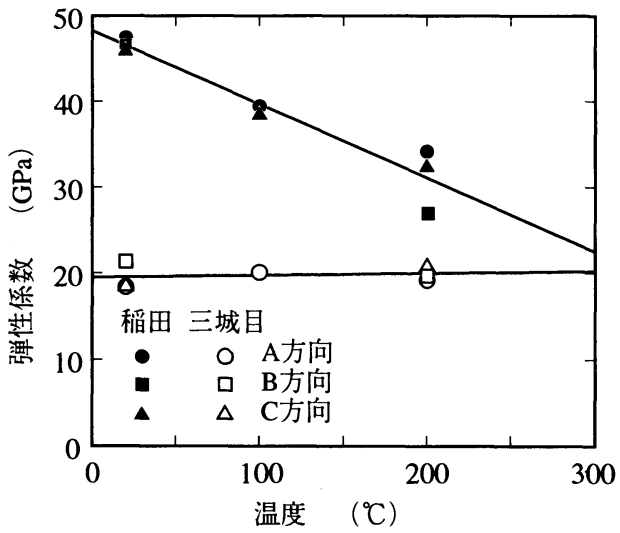

図-13 弾性係数と温度の関係

めた. ヒーター表面温度および供試体側面温度 $T$ の, 加 熱開始からの時間 $t$ 対する変化を次式で表し, 実験時の 供試体側面およびヒーター表面温度の経時変化の実測値 に基づいて, 最小 2 乗法により，その係数 $A_{1}, A_{2}$ および

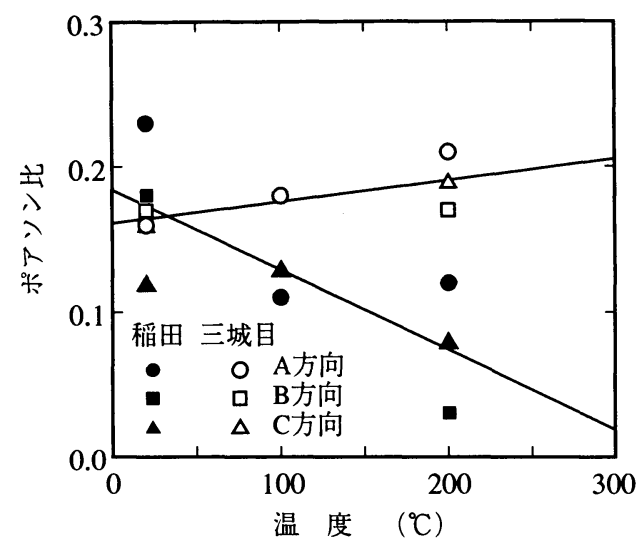

図一14 ポアソン比と温度の関係

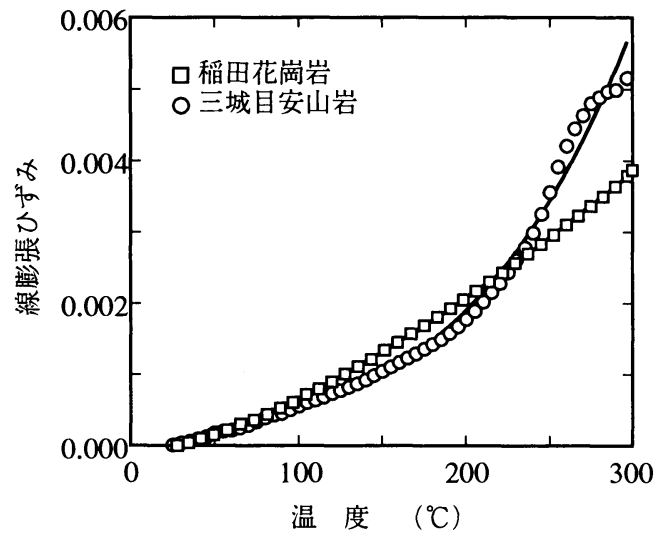

図一15 線膨張ひずみと温度の関係

$A_{3}$ を求めた。

$$
T=A_{1}+A_{2} t+A_{3} t^{2}
$$

解析に必要な岩石の物性値は, 稲田花崗岩および三城 目安山岩のそれぞれについて, 室温から $300^{\circ} \mathrm{C}$ 温度範囲 で実施した室内岩石試験結果4),5)に基づいて決定した。熱 伝導率, 比熱, 静弾性係数, ポアソン比および線膨張ひ ずみについての試験結果を図一11～図一15に示す. 物性 值の温度依存性を考慮しない解析を行う場合には, 室温 $\left(20^{\circ} \mathrm{C}\right)$ における測定値を用いた，直交するA，B，C の 3 方向（A，B，Cは単に直交する 3 方向を区別する ための記号として用いている）について物性値の試験を 行っている場合には，その平均値を用いた．また，物性 值の温度依存性を考慮した解析を行う場合には，各物性 值を温度の関数として定義し, 非定常熱伝導解析の各時 間ステップで求められた温度分布から各要素内の物性を 逐次評価することにより解析に組み入れた。解析に用い 
た各物性値と温度の関係式は以下のとおりである．基本 的には温度に関する 3 次式で近似したが, 測定デー夕数 が多くなく，かつばらつきが大きいため，それが困難な 弾性係数とポアソン比に関しては，1次式で近似した。 各物性值毎に, a)式は稲田花崗岩, b)式は三城目安山岩 についての関係式を表している，なお，熱膨張特性を表 す物性值としては通常線膨張係数が用いられているが, 三城目安山岩のように複雑な熱膨張特性を示す場合の曲 線近似のしやすさから，図一15に示すように，ここでは 線膨張ひずみを用いている.

1)熱伝導率 $k(\mathrm{~W} / \mathrm{mK})$

$$
\begin{aligned}
k & =2.77-1.01 \times 10^{-3} T-9.74 \times 10^{-6} T^{2} \\
& +1.13 \times 10^{-8} T^{3} \\
k & =1.29+2.41 \times 10^{-3} T-5.99 \times 10^{-7} T^{2} \\
& -2.00 \times 10^{-8} T^{3}
\end{aligned}
$$

2)比熱 $c(\mathrm{~kJ} / \mathrm{kg} \mathrm{K})$

$$
\begin{aligned}
c & =0.723+1.57 \times 10^{-3} T-1.38 \times 10^{-6} T^{2} \\
& -1.42 \times 10^{-9} T^{3} \\
c & =0.650+3.71 \times 10^{-3} T-2.36 \times 10^{-6} T^{2} \\
& -2.09 \times 10^{-8} T^{3}
\end{aligned}
$$

3)弾性係数 $E(\mathrm{GPa})$

4)ポアソン比 $v$

$$
\begin{aligned}
& E=48.3-0.0861 T \\
& E=19.5+0.00252 T
\end{aligned}
$$

5)線膨張ひずみ $\varepsilon$

$$
\begin{aligned}
& v=0.184-0.000552 T \\
& v=0.161+0.000147 T
\end{aligned}
$$

$$
\begin{aligned}
\varepsilon & =-1.39 \times 10^{-4}+4.37 \times 10^{-6} T+4.18 \times 10^{-8} T^{2} \\
& -4.05 \times 10^{-11} T^{3} \\
\varepsilon & =-2.21 \times 10^{-5}+4.92 \times 10^{-6} T-1.12 \times 10^{-8} T^{2} \\
& +2.09 \times 10^{-10} T^{3}
\end{aligned}
$$

\section{(2)熱応力解析結果と実験結果との比較}

稲田花崗岩について, 全ての物性值の温度依存性を考 慮した場合（ケース4）の供試体内の熱応力分布の経時 変化を計算した結果を図一16に示す. 図にはヒーター孔 中心から側面の一つへ下した垂線上の応力を示してい る.ここで符号は引張を正としている. 接線方向応力に ついてみると, 円孔中心から約50mmを境にして, それ より内側では圧縮応力が, それより外側では引張応力が 作用しており，時間の経過とともに増大している.

稲田花崗岩の熱破壊実験において, 供試体側面でき裂 か溌生した実験開始94分後における，4つのケースのそ れぞれについての熱応力分布の計算值を図一17に示す.

同図には，熱破壊実験時とほほ同一の条件下（室温，整 形後約 2 週間室内保存, ひずみ速度約 $\left.5.0 \times 10^{-8} / \mathrm{s}\right)$ にお いて一軸引張試験を実施することにより求めた稲田花崗

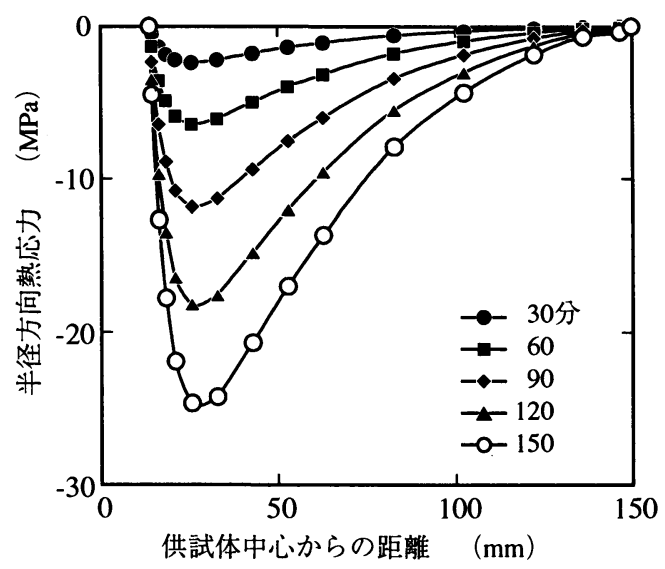

a) 半径方向応力

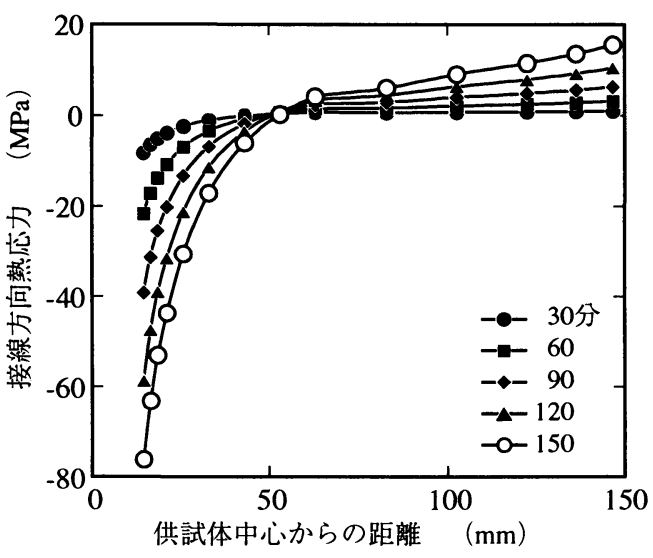

b) 接線方向応力

図一16 稲田花崗岩供試体の熱応力解析結果例(ケース 4)

岩の一軸引張強度の值（3 個の平均值および標準偏差） も示してある. 供試体の寸法は直径 $50 \mathrm{~mm}$, 高さ $100 \mathrm{~mm}$ であり，熱破壊実験において最初にき裂か溌生したのと 同じ方向に引張破壊面が生じるように採取したコアを用 いている. 全体的にケース $1 ， 2 ， 3$ の間の応力分布の 違いはあまり大きくなく，ケース4だけが他の 3 ケース と異なる応力分布を示している。これは，図一11～図一 15からわかるように, 線膨張係数（図一15の線膨張ひず みを表す曲線の勾配）の温度依存性が，比熱，熱伝導 率, 弾性係数といった物性値の温度依存性よりずっと大 きいため，それを考慮したケース4だけが異なった結果 になったと考えられる.なお，ポアソン比に関しては, 他の物性值と比較して, 熱応力解析結果への影響が小さ いため，図一14に示すように，温度依存性がかなり大き いにもかかわらず，それを考慮したケース 3 の応力分布 の計算值と, それを考慮しないケース 2 の計算値との違 いはあまり大きくないという結果が得られている. 


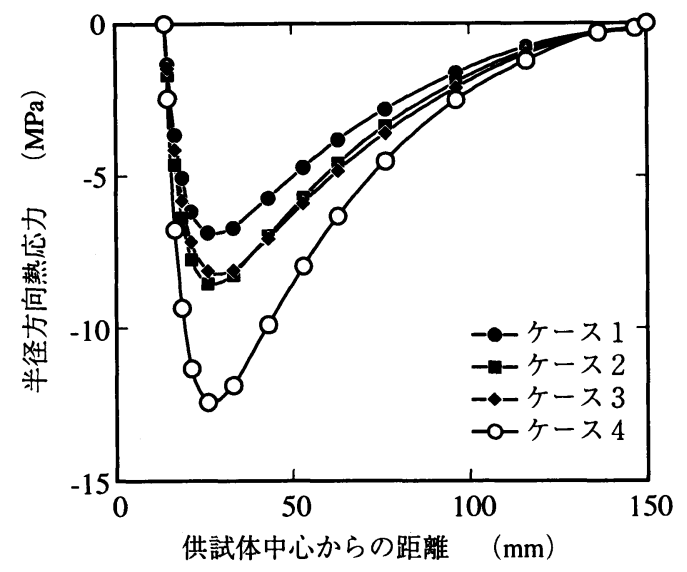

a) 半径方向応力

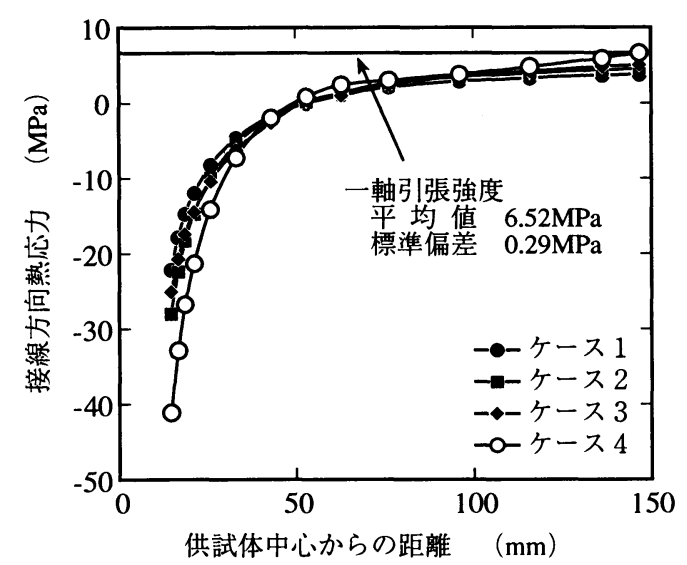

b) 接線方向応力

図-17 稲田花崗岩, 無拘束状態の場合のケース $1 \sim 4$ の供試体破壊時（実験開始94分後）における熱 応力解析結果の比較

ケース 4 では，実験開始94分後における供試体側面で の引張応力の計算値力約6.9MPaに達しており, 熱破壊実 験時とほぼ同一の条件下における稲田花崗岩供試体の一 軸引張強度（約6.5MPa）とほほ等しい值を示している。 それに対して，ケース 1，2，3では，それぞれ約 3.8MPa, 4.6MPa, 5.0MPaとなっており, いずれも稲田 花崗岩の一軸引張強度よりもずっと小さい. ヒーター孔 壁面での接線方向圧縮応力に関しても，ケース $1 ， 2$, 3ではいずれも30MPa以下であるのに対して, ケース 4 の場合は, 約 $41 \mathrm{MPa}$ であり, 線膨張係数の温度依存性を 考慮するか否かによって結果が大きく異なっていること がわかる．ただし，ケース4の場合でも，接線方向圧縮 応力約 $41 \mathrm{MPa}$ という值は, 供試体の一軸圧縮強度 (200 ${ }^{\circ} \mathrm{C}$ で約150MPa）と比較するとずっと小さいので, 供試 体の熱応力による破壊は, ヒーター孔壁面からではなく て, 側面から引張応力により発生するということを示し

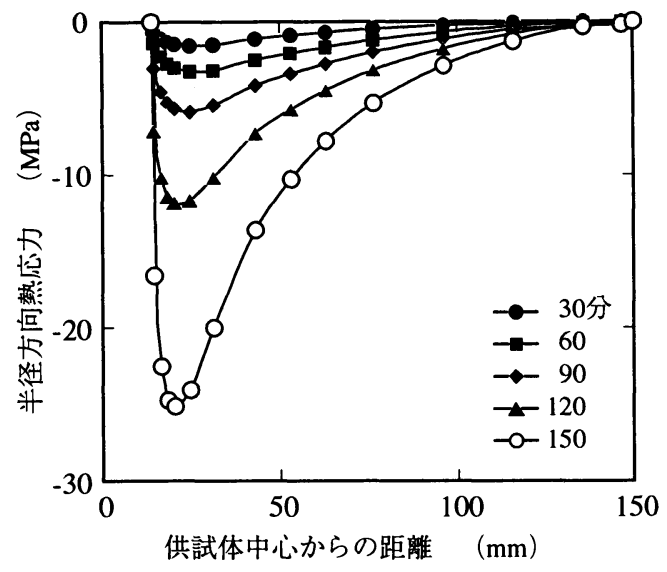

a) 半径方向応力

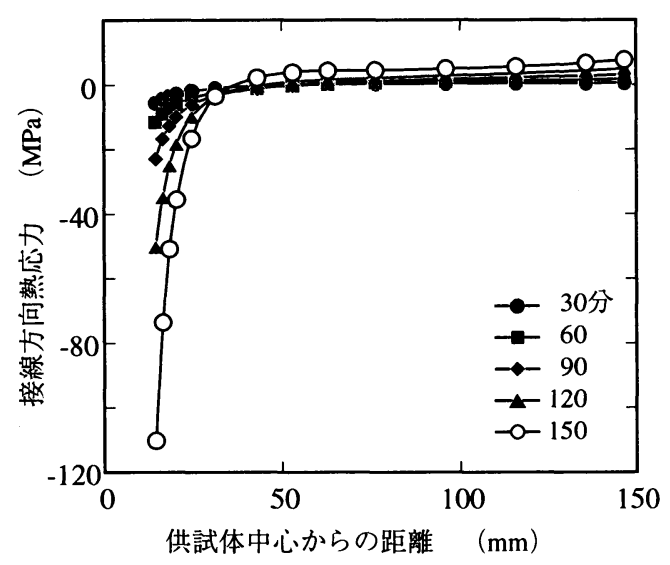

b) 接線方向応力

図-18 三城目安山岩 (無拘束) 供試体の熱応力解析 結果例 (ケース 4$)$

ており, 実験結果と対応している.

無拘束状態の三城目安山岩について，ケース4の供試 体内の熱応力分布の経時変化を計算した結果を図一18に 示す.また，無拘束状態での熱破壊実験において供試体 が張応力により破壊した，実験開始108分後における， 4 つのケースのそれぞれについての接線方向応力分布の 計算値を図一19に示す。稲田花崗岩の場合と同様に, 同 図には，熱破壊実験時とほほ同一の条件下において一軸 引張試験を実施することにより求めた三城目安山岩の一 軸引張強度の値 (3 個の平均值および標準偏差) も示し てある.

無拘束状態の場合, ケース $1,2,3$ の間には, 応力 分布の違いはわずかしかなく, 稲田花崗岩と比較して も, その違いはずっと小さい.これは, 三城目安山岩の 方が, 熱伝導率, 弾性係数およびポアソン比といった物 性值の温度依存性が小さいためである。 


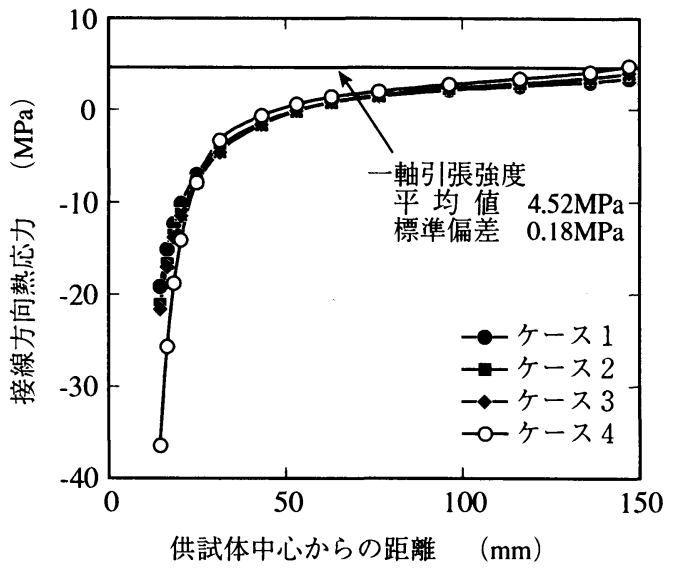

図-19 三城目安山岩, 無拘束状態の場合のケース $1 \sim 4$ の供試体破壊時（実験開始108分後）における接 線方向熱応力解析結果の比較

ケース 1，2，3では，円孔中心から約60mmを境に して，それより内側では圧縮応力が，それより外側では 引張応力が接線方向応力として作用している. そして, 引張応力が作用している領域では, 供試体の側面から中 心に向かって，ほほ直線的に応力値が減少している. ケース 4 の場合は, 引張応力が作用する領域が, 円孔中 心から約 $50 \mathrm{~mm}$ のところまでとやや広くなっている.

ヒーター孔壁面での圧縮応力に関しても，ケース 1 3 とケース 4 との間には顕著な違いがみられる．前者は いずれも20MPa前後の值を示しているのに対して, 後者 は約37MPa と前者に比べて非常に大きな値を示してい る.これは, 図一15から明らかなように, 三城目安山岩 の熱膨張特性の温度依存性は高温になるにしたがって顕 著になっているので, 供試体が高温になるヒーター孔壁 面近傍では，それを考慮した場合の影響が特に顕著に現 れるためであると考えられる.これらの結果から, 稲田 花崗岩の場合も, 三城目安山岩の場合も, 高温下におけ る熱破壊挙動の予測を行う場合には, 線膨張係数の温度 依存性を考慮した解析を行うことが重要であるというこ とがわかる。なお，筆者らの実験結果によれは2), 三城目 安山岩の一軸圧縮強度は, $100^{\circ} \mathrm{C}$ で約 $97 \mathrm{MPa}, 200^{\circ} \mathrm{C} て ゙$ 約 $118 \mathrm{MPa}, 300^{\circ} \mathrm{C}$ で約104MPa となっている. したがっ て，ケース4の場合でも，108分後の孔壁面における接線 方向応力は $36 \mathrm{MPa}$ 程度, 120 分後でようやく $50 \mathrm{MPa}$ 程度 であり，岩石のその温度における一軸圧縮強度よりも ずっと小さく，孔壁面から圧縮応力によって破壊する可 能性は全くないという結果が得られ, 実験結果と対応し ている.

実験開始108分後の供試体側面での引張応力の計算値 は，ケース 1，2，3の場合はそれぞれ3.3MPa， 3.8MPaおよび3.9MPaであるのに対して，ケース4の場

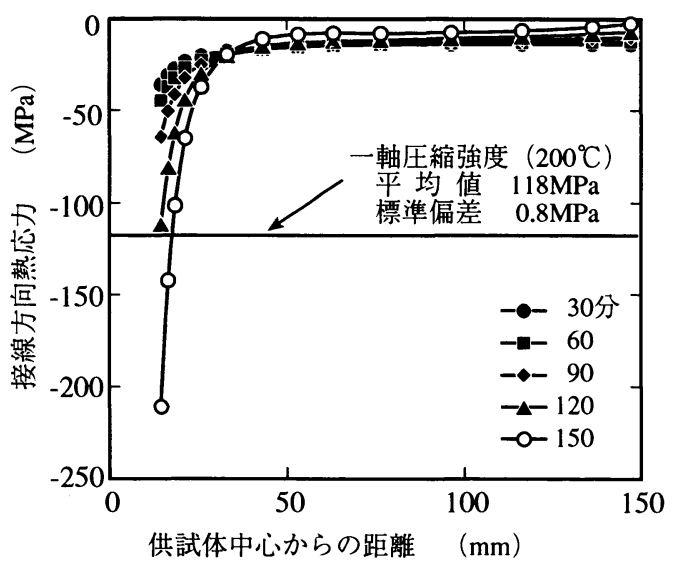

図-20 三城目安山岩, 拘束状態の場合の接線方向熱応 力解析結果例 (ケース 4)

合は約4.7MPa とやや大きな值を示している，一方，熱破 壊実験とほほ同一の条件下において求めた三城目安山岩 の引張強度は約4.5MPaであり, ケース4の計算值とほほ 等しい.したがって, 無拘束状態の三城目安山岩の場合 も, 熱応力によるき裂の発生に関して, 全ての物性值の 温度依存性を考慮したケース 4 だけが実験結果と一致し ている.

拘束圧を14.7MPa作用させた三城目安山岩について の, ケース 4 における接線方向応力分布の経時変化の計 算結果を図一20に示す. 拘束状態では, 供試体全体にわ たって圧縮応力が作用しており, 供試体側面から引張応 力によって供試体が破壊する可能性は全くないことがわ かる. 一方, 孔壁面近傍では, 拘束圧の作用によって無 拘束状態の場合よりも圧縮応力が増大し，破壊しやすく なっている. 図からわかるように, 120分後の孔壁面にお ける接線方向応力は約1 10MPaであり, このときの孔壁

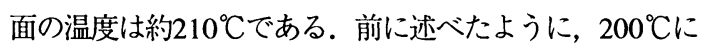
おける三城目安山岩の一軸圧縮強度は約 $118 \mathrm{Mpa}$ なの で, ケース 4 の解析結果からは, 120分後またはそれより も少し遅い時間に，孔壁面から圧縮応力により破壊する ことが予測される. それに対して, ケース1〜3の場合 は, 図には示してないが, 実験開始150分後でも, 孔壁面 における接線方向応力の計算值はいずれも70MPa前後で あり, 三城目安山岩の一軸圧縮強度よりもずっと小さい ので，孔壁面から圧縮応力によって破壊する可能性はな いという結果になっている. 実際の加熱実験では，実験 終了時よりもかなり前にヒーター孔壁面においてき裂が 発生し, その後 $20 \mathrm{~mm}$ 程度き裂が進展していることか ら, 明らかにケース $1 〜 3$ は実験結果と一致しておら ず，ケース4の場合だけが実験結果と対応していると考 えられる。 
以上のような検討の結果, 全ての物性値の温度依存性 を考慮したケース 4 の場合だけが，熱応力による破壊の 開始位置と時間に関して, 実験結果とほほ対応するとい う結果が得られた。これらの結果から, 熱破壊挙動を予 測するためには，物性值の温度依存性が大きい場合には それを考慮した解析を行う必要があり，今回実験と解析 を行った稲田花崗岩と三城目安山岩の場合には, 線膨張 係数の温度依存性をも考慮した解析を行うことが重要で あるということが明らかになった。

\section{5. 熱破壊挙動に対する岩種および拘束圧の影響}

無拘束状態における稲田花崗岩供試体と三城目安山岩 とを比較すると，前に述べたように，前者では，実験開

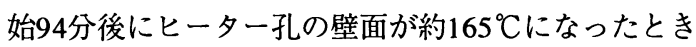
に，外側からき裂が発生しているのに対して，後者で は，それよりもやや遅く，108分後にヒーター孔の壁面が

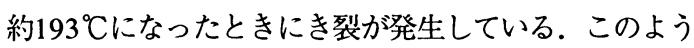
に, 三城目安山岩の方が圧縮強度や引張強度が小さいの にもかかわらず，より高温になるまで破壊しないという 実験結果が得られている. また, 非定常熱伝導・熱応力 解析でも, 同様な結果が得られている.このような実験 と解析結果を踏まえて, 熱破壊挙動に対する岩種の影響 について，より一般的な検討を行ってみた.

円孔周辺に作用する熱応力による破壊について大まか な検討を行う場合には，中空円筒と考えて解析を行うこ とが多く, 定常状態における半径方向の応力 $\sigma_{r}$ およひ接 線方向の応力 $\sigma_{\theta}$ は次式のように表される7).

$$
\begin{aligned}
\sigma_{r} & =\frac{\alpha E T_{i}}{2(1-v) \log (b / a)} \\
& \times\left[-\log \frac{b}{r}-\frac{a^{2}}{\left(b^{2}-a^{2}\right)}\left(1-\frac{b^{2}}{r^{2}}\right) \log \frac{b}{a}\right] \\
\sigma_{\theta} & =\frac{\alpha E T_{i}}{2(1-v) \log (b / a)} \\
& \times\left[1-\log \frac{b}{r}-\frac{a^{2}}{\left(b^{2}-a^{2}\right)}\left(1+\frac{b^{2}}{r^{2}}\right) \log \frac{b}{a}\right]
\end{aligned}
$$

ここで $\alpha, E, v$ はそれぞれ岩石の線膨張係数, 弾性 係数, ポアソン比, $T_{i}$ は円筒内面と外面の温度差, $a, b$ はそれぞれ円筒の内側半径と外側半径である.

この式からわかるように, 定常状態における熱応力 は, 線膨張係数, 弾性係数および温度差に比例する. 今 回実験を行った稲田花崗岩と三城目安山岩とを比較する と, 図一13からわかるように, 後者の方が弾性係数が ずっと小さい. また, 図一15からわかるように, 温度が あまり高くない場合には，後者の方が線膨張係数が小さ い.したがって, これらの影響により, 温度があまり高
くない場合には，図一16と図一18との比較からも明らか なように，後者の方が熱応力がずっと小さい. そのた め, 後者の方か強度が小さいにもかかわらず，より高温 になるまで，熱応力による破壊が生じなかったと考えら れる.

一般に, 強度の小さい岩石は弾性係数も小さいことが 多い. 例えば軟岩と硬岩とを比較した場合, 強度の小さ い軟岩は, 弾性係数も小さいので, 発生する熱応力も小 さい. したがって，熱応力に対する安定性に関しては， 一般に強度の小さい岩石の方が不利であるとは限らな い. 筆者らは，高温下における火成岩および堆積岩の熱 膨張特性に関する実験的研究を実施しており4),8)，その結 果によれば，高温下岩石の熱膨張特性は，岩石の種類に より大きく異なっている．また，力学特性と比較する と, 熱膨張特性の方が一般に温度依存性が大きい. 例え ば, $100^{\circ} \mathrm{Cや} 200^{\circ} \mathrm{C}$ いった高温では，今回実験に用いた 稲田花崗岩や三城目安山岩のように, 室温での線脰張係 数よりもずっと大きな値を示す場合もあれば, 堆積軟岩 のように，吸着水等の脱水により線膨張係数が負の値を 示す場合もある.もしも線膨張係数が負の值であれば, 今回の実験とは異なり，ヒーター孔周辺では引張応力が 作用することになり，今回の実験とは全く異なった結果 になると予想される．したがって，熱破壊挙動が岩石に よって異なるということに対しては, 力学特性が岩石に よって異なるということの影響ももちろんあるが，それ 以上に，熱膨張特性およびその温度依存性が岩石によっ て大きく異なるということの影響の方が大きいと考えら れる.

次に, 岩石の熱破壊挙動に対する拘束圧の影響につい て検討を行ってみた. 前に述べたように, 三城目安山岩 供試体についての熱応力解析結果によれば，無拘束状態 では，供試体の外側から引張応力により破壊することが 予測され，また，拘束圧が14.7MPa作用する状態では孔 壁面から圧縮応力により破壊することが尒測されてお り, 実験結果と対応している.これは, 拘束圧が作用す ることによって, 供試体の外側では引張応力が減少し, 破壊しにくくなっていくのに対して, 孔壁面近傍では, 拘束圧の作用によって圧縮応力が増大し，破壊しやすく なっていくためである.

この結果は; 実際の岩盤構造物の熱応力に対する安定 性は, 構造物の設置深度（初期応力状態）の影響を大き く受けるということを示している. 石塚ら9は，岩盤の一 部が泠却される場合の熱応力解析結果に基づいて, 空洞 の設置深度が浅くなり初期応力が小さくなると, 空洞周 辺岩盤は, 引張応力により破壊する危険性が増大するこ と，したがって，空洞の建設においては，設置深度の影 響を検討することが重要であることを指摘している，岩 盤の一部が加熱される場合は, 線膨張係数が正の值であ 
れば，それとは逆に，設置深度が深くなると，構造物周 辺岩盤は, 圧縮応力により破壊する危険性が増大すると いうことになる. 今回の実験と解析の結果は, 岩盤の一 部か加熱される場合も，やはり，熱応力に対する安定性 について検討を行う場合には, 岩盤の一部が冷却される 場合と同様に, 構造物の設置深度（初期応力）の影響に ついて検討することが重要であるということを示してい る.

\section{6. おわりに}

岩石を加熱した際の熱破壊挙動の特徵を把握すること および加熱に伴うき裂の発生・進展状況の計測手法を確 立することを目的として，高温下において，無拘束状態 の稲田花崗岩と無拘束および拘束状態での三城目安山岩 ブロックの熱応力による破壊実験を実施した．同時に, 岩石を加熱した際の熱破壊挙動を予測するための解析に おいて, 入力物性值の温度依存性を考慮することの重要 性を明らかにするため, 上記の 3 種類の熱破壊実験を対 象にして，高温下における室内岩石試験によって得られ た物性值を用いた熱伝導・熱応力解析を行い, 実験結果 との対比・検討を行った. その結果以下のことが明らか になった。

(1)導電ペイントを塗布する方法およびA E 位置標定の二 つの方法を組み合わせることによって, 熱応力によるき 裂の発生・進展の状況を把握することができた．特に， 引張応力により供試体が破壊する場合には，非常に有効 であることがわかった，ただし，圧縮応力によりき裂が 発生する場合には，今回の方法ではまだ不充分なところ があり, 今後の検討が必要である.

(2)熱応力による破壊挙動は, 岩石の種類や拘束条件に よって大きく異なることが実験により確認された。 その 場合, 稲田花崗岩と三城目安山岩との比較加, 熱応力 に対する安定性に関しては, 強度の小さい岩石の方が不
利であるとは限らないことがわかった。

(3)岩石の熱破壊挙動を予測するために熱伝導・熱応力解 析を行う場合には, 物性値の温度依存性, 特に熱膨張特 性の温度依存性を考慮した解析を実施することが重要で あり，そうすることによって，熱応力による破壊の開始 位置と時間を予測できることがわかった。

\section{参考文献}

1) 石田 毅, 北野晃一, 木下直人, 若林成樹：AEと弾性波速 度測定による花崗岩ブロックの熱破壊挙動の観測, 土木学会 論文集, 第418号/ III-13, pp.153 161, 1990.

2) Young, R. P. : Seismic methods applied to rock mechanics, ISRM News Journal, Vol. 1, No.3, pp. 1-18, 1993.

3) Jansen, D. P., Carlson, S. R., Young, R. P. and Hutchins, D. A. : Ultrasonic imaging and acoustic emission monitoring of thermally induced microcracks in Lac du Bonnet granite, $J$. Geophys. Res., Vol.98, No.B12, pp.22,231-22,243, 1993.

4) 木下直人, 安部 透, 奥野哲夫: 高温, 拘束圧下に扑引火 成岩の熱膨張特性, 土木学会論文集, 第511号/ II - 30, pp.69-78, 1995

5) 木下直人, 安部 透, 若林成樹, 石田 毅: 高温下岩石の力 学特性に関する研究, 土木学会論文集, 第561号/而-38, pp.151-162, 1997.

6) 大久保誠介, 金 豊年, 秋山政雄：一軸引張強度と圧裂弓張 強度の載荷速度依存性, 資源と素材, Vol.109, pp.865869, 1993.

7) S. P. ティモシェンコ, J. N. グーディア共著, 金多 潔 監訳: 弾性論, コロナ社, 1973.

8) 木下直人, 安部 透: 高温下における堆積岩の熱膨張・収縮 特性，土木学会論文集，第517号/田-31，pp.53-62，1995.

9) 石塚与志雄, 木下直人, 奥野哲夫：L P G 岩盤内貯藏空洞の 熱応力に対する安定性の検討, 土木学会論文集, 第370号/ III-5, pp.243-250, 1986.

(1998.4.10受付)

\title{
THERMAL FAILURE BEHAVIOR OF ROCK AT HIGH TEMPERATURES
}

\section{Naoto KINOSHITA, Naruki WAKABAYASHI, Tuyoshi ISHIDA and Koji NAKAGAWA}

\begin{abstract}
Laboratory heating experiments were conducted to investigate the behavior of rocks under thermal stress. The experimental results indicated that the thermal failure behavior of rock greatly depended on rock types and confining conditions. Thermal stress analysis by the finite element method was carried out using the rock properties obtained from laboratory tests at high temperatures. The comparison between the results of this analysis and those of the experiments elucidated that it was essential in the analysis to consider the temperature dependence of rock properties, the thermal expansions in particular. This consideration allows the prediction of the location and time of fracture initiation caused by thermal stress.
\end{abstract}

